\title{
Zenya Takashima: The Wealth of Nations and the System of Productive Powers
}

\section{Translated by Robert Chapeskie and Akio Hoshino}

\section{Introduction by Akio Hoshino}

Zenya Takashima (1904-90)'s 'The Wealth of Nations and the System of Productive Powers,' which has been translated into English here, is Chapter 5 of Part 2, "Adam Smith and the Problem of Civil Society," in The Fundamental Problem of Economic Sociology-Smith and List as Economic Sociologists-, Tokyo: Nihon Hyoronsha, 1941 (The Works of Zenya Takashima, vol. 2, 1997, Tokyo). It was written in the midst of the Second Sino-Japanese War (1937-45) and directly before Japan's involvement in the Second World War (1941-45), a period during which the military system severely suppressed both academic inquiry and the general population. In modern Japan (1868- ), there was a particular emphasis on the introduction of German institutions and culture, and Friedrich List's political economy and its national policy of productive powers were therefore welcomed. This work of Takashima's called into question the prevailing trends at the time, and managed to achieve publication in spite of the severe censorship to which such texts were subjected. Because it talked about "Smith as List" and "List as Smith," the censors seem not to have been able to understand its central critique. Having been written under such circumstances, its prose became very complicated and difficult, but it was covertly held in high regard. It has been said that many of its readers understood its ironic implication, and that some even took it to be a cover for Marxism. Its core chapter that regards Smith's moral philosophy as of greatest importance (Chapter 2: 'Three Worlds in Smith') has already been translated into English (Adam Smith:

The History of Economic Thought, Vol. 61, No. 1, 2019. (C) The Japanese Society for the History of Economic Thought. 
Critical Responses, vol. 5, edited by Hiroshi Mizuta, Routledge, 2000). The theme of Chapter 5 is solely Smith's economic theory.

Although the theory of productive powers in the history of economics appears mainly in List (1841) and Marx (1867), its starting point is in Smith (1776). Smith's theory of productive powers, however, has not necessarily been well understood. In this work Takashima stresses that the "Adam Smith problem' discussed in late 19th century Germany was never a contradiction, that there was a productive powers viewpoint in Smith's The Theory of Moral Sentiments and Lectures, and that the aim of The Wealth of Nations was to analyse 'the increase of productive powers of labour,' not circulation or distribution. Takashima says that a society led by those bearing productive powers who are also the main consumers does not come to be a mercantile or military society, but rather a peaceful and prosperous 'civil society.' There was also Kazuo Ōkōchi's Smith and List (1943), which was composed of similar articles published at around the same time as Takashima's book. These civil society viewpoints were broadly welcomed in the post-war Japanese academy, and can be seen as having formed a major trend. Takashima's book being highly regarded, its Part 2 was separated from the rest of the text and published in a revised and expanded form as Adam Smith's System of Civil Society $(1947,1974)$. Its theory of the productive powers of labour, including in particular its relation to the theory of value, was a topic that Takashima addressed throughout his life, and was still a focus in his last work, Social Science to Challenge the Times (1986). Takashima's theory of civil society was taken up by Kiyoaki Hirata (his former student) and Yoshihiko Uchida, who have also been introduced in this series, and the abovementioned Hiroshi Mizuta (another former student). This is also the case with the other authors featured in this series.

The study of Smith's thought in post-war Japan has thus emerged with this work of Takashima's as one of its starting points. It has several prominent characteristics. It takes Smith having viewed natural factors as the object of labour as a major premise, and also asserts that grasping the relationship between value in commercial society and price in civilised society was 'the greatest difficulty' in Smith's theory. But Takashima does not see this difficulty as fatal, understands 'civil society' as the system of productive powers of labour, and avoids being thrown into theoretical confusion. Instead, he repeatedly emphasises 'the increase of productive powers of labour,' highlights the dynamic character of Smith's theory in contrast to static general equilibrium theory and the totalitarian political economy prevalent at the time, and in doing so, emphasises human productive powers that differ from material productive powers. Takashima went on to address this last issue as an inde- 
pendent problem in 1949, and although his assertions received strong opposition from a few critics at the time he left it to his final work to reaffirm his position. This delay was in large part caused by his having become blind as a result of an eye disease. Notwithstanding these unfortunate circumstances, the author published many enlightened works concerning social science and social thought. In his last work he returned to this essay's viewpoint of 'civil society as the system of productive powers,' an approach that can be seen as raising very important questions. In brief, while the worldwide study of The Wealth of Nations has until now consistently insisted on its failure, especially in the case of rent theory, this work on the contrary tacitly suggests that 'the increase of productive powers of labour' was so successful in its logic (macro-dynamics) as to make Smith's so-called 'confusions' secondary and harmless.

To sum up, Takashima's study of Adam Smith's thought is characterised by the following three points.

(1) The system of civil society that Takashima understood was composed of the three worlds of morality, law and economy, and was presented in two major works and a lecture. Here there is a paradox in that although the logic of sympathy underpins the world of justice that includes political economy, in reality the logic of political economy sustains the worlds of justice and morality. This understanding was welcomed as a new perspective in Japan.

(2) This work's discussion of economic theory was restricted to Chapter 5, and Takashima later sought to remedy this deficiency. Chapter 5 thus has a tendency to engage with its subject matter in purely methodological terms. It criticises both List's political economy and general equilibrium theory, and insists that their basis is not only the theory of productive powers of labour but also the labour theory of value.

(3) The work's dynamic viewpoint and critique of data are similar to Hayek's (1949) and anticipate today's endogenous growth theory (1990- ). Takashima, however, discussed these not as equilibrium theory but as the theory of productive powers of labour. We can therefore say that this work continues to possess no small significance even today.

\section{$\langle$ Explanatory Notes〉}

1. Text in [] was inserted by the translators.

2. The 'beautiful nose' example in The Theory of Moral Sentiments in the Section 1 (p. 73) is in fact not Smith's viewpoint but that of another author. 


\section{[Introduction]}

It was Adam Smith's fundamental belief that the sole aim of production is consumption, and that the interests of producers should only be considered to the extent that they promote the interests of consumers (The Wealth of Nations, p. 625 [ed. Edwin Cannan, The Modern Library, New York]). Smith thought this maxim was so self-evident that it would be foolish to undertake any effort to prove it. It is well known that it was here he sought the ultimate basis of his criticism of the mercantile system; after all, in mercantilism, 'the interest of the consumer is almost constantly sacrificed to that of the producer; and it seems to consider production, and not consumption, as the ultimate end and object of all industry and commerce' (ibid.) Smith therefore asserted it was not so difficult to determine who had conceived this mercantile system, and exposed the producing class, and within it in particular the merchant and manufacturer classes, as its architect (ibid., p. 626). On this basis, as far as material well-being was concerned, for Smith the interests of society as a whole were congruent with the interests of consumers. And since the vast majority of consumers belonged to the working class, in practice the interests of society were in accord with those of the working class. The fact that the interests of the capitalist class, on the contrary, often conflicted with those of society as a whole, was clearly the determination at which he arrived in the concluding section of Book I of The Wealth of Nations (ibid., from p. 247). While the assertion that the interests of the landowning class are consistent with the interests of society as a whole may call to mind a physiocratic influence, we will not discuss this any further here.

There are two lines of thought that should be highlighted in Smith's consideration discussed above. One is Smith's division of civil society into three producing classes: workers, capitalists, and landowners. The other is that, while taking this view of social classes, Smith adopts a stance that transcends and critiques it, namely, the stance of the consumer. Given these two positions, Smith's approval of the interests of the working and landowning classes is not given for reasons of class, but rather in accordance with the interests of society as a whole, and his occasional disapproval of the interests of the capitalist class, too, is not based on this class itself. To put it another way, the stance of the consumer is nothing other than a concrete embodiment of 'justice' in the economy, and as a result, it is almost self-evident that the interests of the capitalist class, to the extent that they do not violate the law of 'justice,' not only cannot be condemned but must indeed be praised. Smith's condemnation was reserved for 'projectors' and those in league with corrupt 
politicians, not capital as the driving force in modern civilisation. What he condemned was also a collusive, factional mentality that monopolised one's own interests, while taking advantage of the ignorance of the general public of consumers, not a spirit of fair play among capitalists. As a result, the assertion that the sole purpose of production is consumption did not make The Wealth of Nations a system of 'welfare economics,' nor did it constitute an example of 'household economics.' It was to all extents the system of production, and of productive powers. As he had already shown in his Lectures on Justice, Police, Revenue and Arms: Delivered in the University of Glasgow, while human economies develop out of our three fundamental desires for food, clothing, and lodging, Smith's inquiry concerned not the various aspects of these desires but the systems of technology and productive powers whose development they engender. He was thus able to begin The Wealth of Nations not with desires but with the division of labour. In other words, as Amonn notes, for Smith the problem of the satisfaction of desires was self-evident (A. Amonn: Adam Smith und die Grundprobleme der Nationalökonomie. Zeitschr. f. d. ges. Staatsw. Jg. 80 [1925-26, p. 576]). The process of the production of the wealth created by this kind of technology and productive powers, the process of its allocation among the various social strata, and ultimately the process in which reproduction and accumulation occur through the first two processes and supply nourishment to society as a whole in the form of consumers-these three fundamental processes were what interested Smith directly. As a result, making the system of civil society seen by Smith into a 'system of desires' (Hegel), in the sense that desires as its starting and ending point include a production mechanism as a midpoint, even if it is not inherently mistaken, can be faulted for being limited to an idealised understanding that does not touch on the actual state of what is objective. This does not amount to taking it as a system of productive powers in earnest. On the other hand, because of production, distribution, and accumulation, all occurring through the mediating mechanisms of exchange and price, attempting to grasp Smith's civil society as a single circulation process has been seen as the 'royal road' in modern economics. This cannot be accepted, however, by us who are aware that, at least in Smith, production is the substantial regulating principle of civil society and social culture. Of course, we also know that civil society is a circulation process, the process of money, price, and exchange, and that in this sense civil society is an exchange society (Tauschgesellschaft). But circulation is the mediating process of productive powers, not vice versa. Those fixated only on the superficial surfaces of price in daily life will presumably formulate and abstract human socio-economic relationships under this aspect of circulation, but those who aspire to a sociological understand- 
ing of civil society at the same time know the overcoming and sublation of this kind of circulation view. For us, distribution and exchange are the starting point of analysis, not its conclusion. This comes from the same mindset with which Smith turned to mercantilism and said that money is the image of wealth, not its substance. As a result, for us The Wealth of Nations must be addressed as a system of productive powers. To take things in order, however, we must begin with a brief look at the process of circulation as a starting point.

\section{The Process of Circulation as a Starting Point}

The chapter on the division of labour, positioned at the very beginning of The Wealth of Nations, has a truly wondrous character. As I will discuss later, not only does it possess fundamental importance as an analysis of production processes, but even at this early stage we cannot avoid seeing Smith's ideas concerning distribution being held strongly, and at the same time this theory of the division of labour can also be seen as a general theory of circulation processes. This is the case because here Smith not only addresses the division of labour within factories as a factor in the productive powers of labour, but as has been made clear by Bücher (Karl Bücher: Die Entstehung der Volkswirtschaft, 1893, Bd. I.), for example, also includes in his discussion what is referred to as the 'social division of labour.' In contrast to the division of labour within factories, which, as Smith says, presumes the accumulation of capital, the social division of labour on the contrary presumes the dispersion of capital. As a result, the roles these two forms of division of labour play in a capitalist society differ. But it is clear that the division of labour within factories presumes the progress and increasing complexity of the social division of labour, and that conversely along with the increasing complexity of the social division of labour, division of labour within factories too advances, because 'the division of labour is limited by the market.' The social division of labour and the division of labour within factories thus operate on each other through the market. The market becomes the place where these two divisions of labour are mediated, and since the total amount of wealth cascading down from the division of labour within factories is distributed throughout the strata of the social division of labour through the medium of the market, it must be noted that the idea of distribution comes into play here. Simply stated, the workings of a civil society operate through exchange and the market, and money becomes a concrete embodiment of the mediating function of this 'complicated mechanism.' According to Smith, therefore, in a society in which the division of labour and exchange occur, 
'Every man thus lives by exchanging, or becomes in some measure a merchant, and the society itself grows to be what is properly a commercial society' (The Wealth of Nations, p. 22). In this kind of present-day interpretation of Smith, his theory of the division of labour has not only given the classical interpretation of a technological division of labour, but has also come to be seen as generally illuminating the fundamental structure of exchange or circulation societies. The view of Professor Amonn cited above is an excellent example of this perspective, and at present this is considered the proper approach. This is taken to be the case because of the sense that on this basis Book I of The Wealth of Nations is almost completely concerned with the issue of a theory of price, and the issue of distribution seems to have been dealt with as ancillary to this theory. Rather than content ourselves with this conclusion, however, let us examine this issue further.

As Smith says, civil society as an economic society is first and foremost a commercial society. This is because in a commercial society not only are overall relationships of dependence between people made concrete to the point they are visible through money, but it is also through money that they are rationalised, reduced to a common measure, and made exact. Qualitative differences between people are made quantitative, and, as Smith also says, the differences between a philosopher and a day labourer are acquired rather than innate. In ancient and medieval times people were not capable of thinking this way. They welcomed the quality of goods improving through the division of labour, but were not happy about their quantity increasing. In this sense Smith's theory of the division of labour corresponded best to the fundamental character of modern civil society. This being the case, in a society in which the division of labour is implemented, the principle of equivalence must also be put in place. Equivalence means economic benefits and counter-benefits being the same, and this is the realization of what is referred to as justice in the economy. Or, to put it more accurately, it is the realisation of justice in circulation, and this in turn presupposes the equivalence of economic agents. In other words, here economic agents no longer act only out of benevolence, but are considered economic atoms insofar as they act out of self-interest. The principle of equivalence calls for this kind of quantitative individual view. In Smith's 'commercial society,' therefore, the issue is no longer its individual agents, but its mechanism and the process of its motion created by multiple individuals, and Smith viewed the process by which this mechanism operates, first and foremost, as the process of equivalent exchange. As a result, the form of equivalent exchange is a social process from which nothing can be obtained by appealing to the psychological motivations or internal experience' (Amonn) of individuals. Here even if explanation by 'assigning 
motives' is not necessarily useless, it cannot be described as useful. On the contrary, true analysis is thought of as beginning at the place where this kind of 'prescientific' understanding ends. This is the case because from the start Smith's methodological stance was one of understanding social processes as social processes from the perspective of a well-informed third party. As a result, the form of equivalent exchange in Smith, even if it does not render subjectivist explanations useless from the start, nevertheless means it is something that should be analysed independently of them. It seems that the reason those who take a subjectivist approach, from Menger to Amonn, cannot understand the orthodox school well is that they cannot sufficiently come to grips with the significance of equivalent exchange in Smith. The fact that after originally starting out from equivalence Smith later wound up arriving at the principle of 'utility and scarcity' in regard to the problem of rent, and in particular absolute rent, was undoubtedly Smith's own contradiction (Amonn, ibid., p. 648), but it does not mean that, as Amonn asserts from his subjective standpoint, Smith ended where he should have begun this inquiry. A further level of clarity is obtained by analysing Smith's view of market price and natural price.

Smith's discussion of market price and natural price, and the difference between these two prices, can truly be said to have laid the first mile of the long road leading from the publication of The Wealth of Nations to today's theoretical economics. Smith provided a ground-breaking expression of the distinction between market price and natural price, or nominal price and real price, that had gradually come into use in Britain from William Petty onward. To begin with, in contrast to market price that was the actual price determined by the relationship between supply and demand, natural price was defined as the central price that arises at the point where supply and demand are concordant. This way of thinking of natural price, as the 'centre of repose and continuance' of actual price that fluctuates above and below it under the influence of the relationship between supply and demand, comes directly from Smith's idea of moderation in The Theory of Moral Sentiments, and is reminiscent of the passage in which he speaks of the truly beautiful nose being neither too long nor too short and its differences from every particular nose less than their differences from each other. In other words, in Smith moderation arises at the midpoint between two extremes, and is by no means the average of all particulars. Natural price is in this sense a central price. But in this case 'price' is something that deals with the quantitative world, and what distinguishes it is its being discussed as though it were realised as a result of free competition. That is to say that concordance of supply and demand is not merely something to be imagined but should actually be realised, 
and natural price, too, is thus not merely an imagined price but is thought of as being realistic in the most specific case of market price. We must note, however, that something that is in a sense metaphysical insofar as it transcends experience lies submerged in this idea of a central price as a midpoint of two poles. Smith ties this midpoint idea to the idea of natural law and there conceives the world of natural price, but even if natural price is explained in accordance with market price, that is, even if it is a central price that is ultimately realised through the process of free competition, free competition is neither the only means by which this central price can be realised nor something that directly constructs the concept of central price. To be sure, this central price itself may conceivably move in accordance with various market price circumstances. The centre of repose and continuance, however, is another matter. This was not simply something based on experience but something that transcended it; it was not something that could simply be considered the consequence of free competition, but rather a logical basis that necessitated the policy principle of free competition. In other words, even if empirically this central price had never been realised at all-and was not something to be realised in actuality-it would still not be something that stopped constituting the real price, nor would it be something that stopped constituting the 'gravitational price (Gravitationspreis)' that pulled individual market prices towards itself. Smith being able to think like this was owing to his principle of sympathy as the principle of harmony, and as a result for Smith the world of natural price was the world of economic harmony and was capable of expressing the economic whole. Smith therefore thought of this world of overall harmony being realised 'of its own accord' through the principle of laisser-faire as being most suitable to the "natural course of things, and Smith's view of market price and natural price cannot be understood separately from these sorts of methodological foundations and practical desires.

As a result, for Smith, the theoretical analysis of the process by which individual market prices formed the natural price was not important. What was critical to him was the structure of the natural price, not the process through which it arose, and how to prove that this was the most desirable price possible. Just as subjective explanations had had no positive force when it came to explaining the form of equivalent exchange, they were equally incapable of contributing to an explanation of natural price. This was the case because from the start Smith assumed a relationship between fluctuations in supply and demand, and thus always assumed a theory of supply and demand in whatever form it might take. Modern economics, however, emphasises this process, and sees in it one of the general deficiencies in the orthodox school. 
Regarding this point, the development of modern theory has indeed been remarkable. There is of course much we must learn from it. But even though modern theory, not satisfied with the straightforward understanding of the quantitative equality of demand and supply, proceeded to analyse the demand curve and the supply curve, and, without adhering to the average principle, managed to employ the subtle niceties of the marginal principle, what does it mean for us that in the end this once again restored the character of a theory of supply and demand? Looking back, Carl Menger and Eugen von BöhmBawerk opposed the orthodox school's form of equivalent exchange, finding at its root on the contrary inequivalent exchange, and using this approach 'went deeper' to the world of utility and subjective value. It is widely known that on their return to the phenomenal surface of social processes after undertaking this 'deepening' they could not help adopting the form of 'price formation.' Even if in one aspect this became a factor in the move toward natural science among subjectivists, in another aspect it must also be said that this approach stood on a firm foundation as a theory of price. This was because in explaining price through things other than price it employed the same scientific method as Smith. Regarding the fact that price formation theory had no choice but to become price fluctuation theory when it became clear that price was by no means something 'formed' by utility and subjective value, and on the contrary, these sorts of subjective elements were no more than causal factors included within the world of objective exchange value, it became self-evident that, where it had been thought that the subjective school 'deepened' the orthodox school, the former had in fact done nothing more than made the latter abstract. The emergence of equilibrium theory as a form of development of the marginal utility school must indeed be described as a natural outcome. We are not engaged in a critique of equilibrium theory here, but it should be discussed to the extent it may be useful in making clear Smith's natural price theory. That is to say, the marginal utility school tried to discuss 'price formation' by following a path from subjective use value to subjective exchange value and then from subjective exchange value to objective exchange value, but in every sense the development from there to equilibrium theory indicates an abandonment of this plan. Moreover, this development amounted to nothing other than a confession that pure economics had in principle returned to the world of market price found in Smith. Even if it was no longer Smith's straightforward theory of supply and demand but a new theory of supply and demand with a higher significance, there is no need to belabour the fact that its field of view in principle did not go beyond the process of circulation as a starting point. Equilibrium approaches, however, no matter what sort of explanations are attempted regarding their 
theoretical character, originate from natural price as a central point in Smith, and the modern economics that returned to a new supply and demand theory therefore required once again a new theory of natural price. Smith's natural price was thus both alpha and omega for all schools of economics. As it turns out, the view of harmony included in Smith's natural price cannot be stripped away from the modern equilibrium approach, and has acquired modern expression in forms such as equilibrium being thought of as the essence of an economy or as a mathematical limit. But whereas the idea of pre-established harmony in Smith possessed ample significance within the context of the era in which Smith lived, it clearly came to be a dogma when pre-established harmony elements became problematic in equilibrium theory. Even if equilibrium is considered simply as a means of theoretical support, this can easily be transformed into a policy concept by turning it into a desirable ideal state, and here it does not seem that the metaphysical character of equilibrium theory can be concealed. Of course, that is not to say that this metaphysical grounding was not present in Smith. What we want to assert is that what was permissible in Smith is not necessarily permissible in equilibrium theory, because in Smith there was always a deep and broad-based philosophical and sociological foundation.

As stated above, in Smith the circulation process was merely a starting point. It was natural price as distinguished from market price that was the target of Smith's consideration. He approached this target from two directions: 1) natural price as the sum of wages, profit and rent, and 2) natural price as real price. The first problem guides us toward civil society as a process of distribution, while the second leads us to civil society as the process of the production (and reproduction) of value. Let us begin by considering the first of these issues.

\section{Civil Society as a Process of Distribution}

We have already noted at the beginning of this [previous] section that Smith's theory of the division of labour included a view of distribution, or more generally allocation. As is widely known, the concept of distribution in Smith is one he learned from the physiocrats, and as a result, the various issues of distribution theory can be seen as superfluities that have been mixed into Smith's economic theory system, and it is usually thought that this caused him a great deal of confusion. Discussing the relationship between the Lectures Delivered in the University of Glasgow and The Wealth of Nations, for example, Professor Cannan writes, 'The dissertations on the division of labour, money, prices, and the causes of the differences of wages in different employments, evident- 
ly existed very nearly in their present form before Adam Smith went to France, and the scheme of distribution, on the other hand, was wholly absent. It is plain that Smith acquired the idea of the necessity of a scheme of distribution from the physiocrats, and that he tacked his own scheme on to his already existing theory of prices' (Cannan's 'Editor's Preface' to Lectures, p. xxxi). On this point, however, the 'Draft of The Wealth of Nations' discovered by professor Scott tells a different story (Scott, W. R., Adam Smith as Student and Professor, 1937. Part III: An early draft of part of The Wealth of Nations.) According to Scott's research, this draft was written after the Lectures and before Smith's departure for France (1763), and should be viewed as a revision of the Lectures (ibid., p. 319). What Scott discovered was only part of a draft, and the scope of what it addresses is limited to issues concerning the division of labour, money, and price, but as Scott says, the scope of the issues concerning distribution Smith addressed at this stage was much larger than had been imagined, and attention must be paid to the width of the field of view and lucidity of this treatment. In this draft Scott was not only able to see extremely clear concepts of national distribution and real national distribution, but also says that the division of profit and wages was acknowledged while in other places there are several mentions of rent, and notes how strange it is to see the division between productive and unproductive labour staring back at us on the first page of the manuscript (ibid., p. 320). Dugald Stewart had already reported that Smith's making the division of price 'rent, capital profit, and payment for labour' had been owing to a hint from James Oswald (ibid., p. 320), and regardless of the merits of this claim it can presumably be described as sufficient favourable evidence to encourage us to undertake a particular reconsideration of the importance of the concept of distribution in Smith. It can thus presumably be understood that 'commercial society' as the process of circulation in The Wealth of Nations had at the same time been thought of as a process of distribution from the start.

But we must of course note here the following point. Smith's having understood the process of circulation at the same time as a process of distribution does not mean that he received no influence from the physiocrats, nor does it mean he displayed no confusion regarding the solution to the problem of distribution. While thinking of natural price as being formed out of the sum of normal or average wages, profit, and rent, or, in other words, natural wages, profit, and rent, on the one hand he understood these components of price as nothing more than divisible parts or resolved elements of natural price as a whole, and on the other hand he made the seemingly self-contradictory assertion that while rent was a component of price like wages and profit, at the same time it was not a causal factor of an increase in price but 
on the contrary its result, and thereby fell into a near fatal confusion. This has been pointed out by many scholars, beginning with Amonn. It is also said that Smith inherited the concepts of annual production, gross revenue, and net revenue from the physiocrats, along with their fundamental categories concerning the classification of capital, and this led to other confusions in Smith's theory of distribution. One example of this is the apparent confusion of wealth as capital and wealth as income (Edwin Cannan, A History of the Theories of Production and Distribution, 1924, p. 14), and the famous account of productive labour and unproductive labour in Book II of The Wealth of Nations, too, is plagued by this in more than a few places. While at one point thinking of the distribution process as a question of the composition of price, or in other words simply as a question of the process of circulation, at the same time Smith understands it as a question of the distribution of products. Smith's having thought of the issue of distribution not as simply an issue of price but as one of the distribution of wealth is evident in the abovementioned 'Draft of The Wealth of Nations' discovered by Scott, as well as in the introduction and first chapter of the The Wealth of Nations itself, and it can be surmised that he came to hold this belief even more strongly after encountering the 'Tableau économique.' This is the case because the 'Tableau économique' did not simply reveal the process of circulation, as is the general view, but also the processes of social production and reproduction, and as a result addressed the issue of the process of the distribution of social wealth. There were thus clearly things that Smith learned from François Quesnay's idea of gross income and net income, or, in other words, gross social product and net social product. The category of income as net social product, however, clearly differs from the category of income as price, and even if goods as price are resolved into wages, profits, and rent, goods as gross social product cannot be resolved in this way. If they were, the process of the accumulation of capital described in Book II of The Wealth of Nations would immediately come to a halt. This is the case because according to Smith the accumulation of capital arises out of the net product that results from annual production exceeding annual consumption through 'parsimony, and cannot ever occur through a cumulative increase in money price. This kind of confusion in Smith's theory of distribution shows that he had not yet fully digested the 'Tableau économique.' But our aim is not merely to point out confusion. What does this kind of confusion in Smith tell us? First, it tells us that we can only properly understand the internal relationship between Books I and II of The Wealth of Nations by moving on from the issue of merely circulation and delving into the issue of distribution, and that Smith lacked sufficient grounds to separate these two books. Indeed, in his 
introduction to The Wealth of Nations Smith describes the subject of Book I as the causes of increases in the productive powers of labour and the natural distribution of the wealth thus obtained, and concludes that, since when the state of the productive powers of labour is fixed the amount of wealth depends on whether capital is directed towards productive or unproductive labourers, the issue of capital and accumulation should be addressed in Book II. But Smith evidently lacks sufficient awareness of the fact that these two issues are in fact one and the same. He does not seem to have realised that his confusion regarding natural price was a stumbling block in unifying these two subjects of inquiry. However, this is not the only point on which we can learn something from this confusion in Smith. Another is that the issue of distribution is not merely a question of circulation, but at its foundations involves questions of production and productive powers. Smith's having resolved price into the three factors of wages, profits, and rent already includes an element that cannot be explained by viewing civil society as simply a circulation society: when it comes to the problem of the distribution of social product, people do not interact with each other as equals on a quid pro quo basis, but rather in terms of a concrete unity of social and historical concepts. Namely, they interact with each other as individuals with a particular status, as a class, or as the heads of households. It is clear that since Smith saw civil society as a class society, he positioned workers as those possessing labour power, capitalists as those possessing capital, and landowners as those possessing land at the foundation of distribution, and from this starting point, he then obtained his three forms of income: wages, profits, and rent. What is most striking is that these were furthermore brought into the process of circulation as the elements of price. But these three classes of workers, capitalists, and landowners were not themselves phenomena of circulation or phenomena of distribution; on the contrary, they were foundational categories for the process of production. This was the case because they represented social and historical relationships of dominance regarding the three elements of production. Smith took this as a historical given, and at the same time rendered it super-historical by making it a component element of natural price. Without getting into a detailed discussion of these points here, what we can learn from them is that the process of distribution is not something that can ever be considered separately from the process of production; on the contrary, it is something that takes the position of a medium that should lead our investigation from the process of circulation as a starting point of consideration to the process of production as an actual starting point. Smith himself did not say this. His confusion, however, conveys it to us. This is the case because social product being completely dispersed among all social classes 
through the social relationships of dominance regarding the three elements of production is a core belief supporting Smith's laisser-faire thought, and as a result, the increase of productive powers as the only source of an increase in production becomes Smith's theoretical foundation along with his policy appeal.

We can say that by understanding the process of circulation as a process of distribution as described above and taking this examination further to arrive at the process of production, Adam Smith's commercial society came to be no longer a society of merchants but a society of producers. More precisely stated, it was a society of producers in which each person, through the division of labour and exchange, became to some extent a merchant, that is, an exchange society of producers. At this point it goes without saying that this was defined by the practical character of the orthodox school in general. Society as seen by Smith, Ricardo and Malthus was to begin with a society that produces wealth, not merely a society that distributes wealth or a society that circulates wealth. Nor was it anything like an evaluation society whose foundation is the satisfaction of desires. As a result, I think an approach that diverges from the concept of distribution used by Smith, formalises it, and tries to find a concept of allocation therein is, at least as an interpretation of Smith, incorrect. This is the case because this kind of interpretation stands on a conception that simply makes the process of distribution one of circulation, and, so to speak, replaces the justice of distribution with the justice of circulation. Even if this manages to avoid the deadlocked position into which Smith fell when he became caught between the problem of price and the problem of distribution, it is difficult to say it displays the fairness of "sympathy' for Smith's proper bemusement. Smith believed in the self-explanatory nature of profit, but on the other hand, he acknowledged the social disadvantages of the working class as people who got wages. Consumption is the goal of production, and since the working class makes up the great majority of society, the goal of production is of course to be found in the increase of the welfare of this class. Evidence of the warm, humanistic sympathy Smith displayed toward this class abounds throughout his work. How willing Smith was to engage in rich, historical, sociological consideration of these three classes as the foundational classes of a civil society, including that of landowners as those who obtain rent, is evident in the first two books of The Wealth of Nations, said to be the most purely theoretical part of this work. Nothing could be easier for us than to find many faults in Smith's theory of distribution. But I believe it is clear from what I have said thus far that bringing modern eyes immediately to bear to rescue this theory will not necessarily save Smith. Here too we must go along with him as far as we can, 
because this is the true meaning of 'sympathy' in Smith.

\section{Processes of Production and Reproduction: The System of Productive Powers}

The American sociologist A. W. Small dubbed Book I of The Wealth of Nations the 'sociology of labour' and Book II the 'sociology of capital' (W. A. Small, Adam Smith and Modern Sociology, 1907). There is a great deal the view of Smith's system of economics as a system of sociology in this approach can teach us, but the complaint can be made that in clinging to the classification of The Wealth of Nations itself it cannot be said to have attempted to understand Smith in a unified manner. From our point of view, throughout its entirety Smith's system is both a sociology of labour and at the same time a sociology of capital. As we have seen, Smith's 'commercial society, while being a society of distribution, was ultimately a society of production, but the so-called 'trinitarianism' of income, namely, the idea that labour power, capital, and land are positioned as the sources of income for wages, profits, and rent respectively, was not originally present in Smith. He saw the three means of production merely as the basis of the formation of forms of income, and did not think of them as going on to constitute the sources of income. This is only something that emerged from the interpretation of Smith in Jean-Baptiste Say. That Smith did not think of the three elements of production as sources of income directly is indicated in particular by the fact that he did not give an unequivocal explanation of profit, and that regarding capital he thought about interest and distinguished between interest and profit. It is already implausible, therefore, that Smith considered in the process of distribution anything other than land and labour as sources of income. Wages, profits, and rent can also be thought of independently as sources of value, and it is not impossible to find descriptions of it as something added by workers, but the assumption that on the whole land and labour are what creates income and that profits are self-explanatory is characteristic of Smith's approach. Looking at it from another angle, however, in Book I between land and labour, it is the 'annual labour of every nation' that is considered exclusively as the foundation of producing income ('necessaries and conveniences'), and going forward, particularly when it comes to the theory of rent, nature's working in collaboration with human beings is described as the source of the formation of rent as surplus over and above the average profit. Moreover, while he writes of 'the real wealth, the annual produce of the land and labour of the society' at the end of the introduction to The Wealth of Nations, there is ample grounds to believe this introduction was 
written later (in the 'Draft of The Wealth of Nations' discovered by Scott the introduction is completely absent, and the text begins from Chapter 2). In this sense, therefore, we can presumably view Book I more or less as Small did as the sociology of labour. This does not mean, however, that nature can be completely ignored. Based on the impression we have already received from the Lectures, too, we can see Smith as expressing nature in general through land, and what is human in general through labour, and here we can understand the concept of wealth in Smith as the unification of the natural and the human (cf. E. Leser, Der Begriff des Reichtums bei Adam Smith, 1874). Production, in sociological terms, is work carried out on nature by human beings, and there we find the meaning of labour. As a result, to say that Book I of The Wealth of Nations is developed with labour as its cardinal point by no means implies that nature is ignored. Since from a sociological standpoint nature is the mother of wealth and labour is its father, in this sense we can accept the emphasis on labour in Smith. As is widely known, Smith can be seen as a reconciler of the mercantilists and the physiocrats (Amonn also sees him this way), and Smith being described as someone who consolidates these two approaches can first and foremost be found in the special role he assigns to labour. That is to say that Smith's labour emerges as a unification of mercantilism's money-centred approach and the goods-centred view of the physiocrats in which money is nothing more than a means of circulation. According to Smith it is labour-by which of course he means labour applied to nature-that is the sole creator of wealth, and as a result he thought it was possible for it to become a measure of exchange value. To say that the members of the orthodox school beginning with Smith adopted the standpoint of producers implies, one must also point out, that they had to adopt a labour-centric view in their theories of value and price. As a result, even if Smith's use of labour in establishing the central concept of his theory of value is quite a stretch and his explanation of this point once again piles confusion atop confusion, there is still much we must learn from his fundamental awareness that civil society is a system of labour; it is this view that teaches us the sociological understanding of the economy as work performed on nature by human beings, or, more precisely, as the social process of labour. Amonn sees Smith's use of the concept of labour to explain value as having come from a practical perspective, and believes that this confused his purely theoretical analysis (op. cit., pp. 580, 609). There are many points on which we should listen to Amonn's incisive critique of the labour theory of value, but we cannot conclude that Smith was practical and therefore not theoretical. On the contrary, it was precisely because he was practical that Smith was able to see through the circulation aspect of civil society and observe the 
world of labour deep at its roots. What Smith saw was not merely money or goods, but a higher perspective that included both of them, and it was for this reason he was able to speak about increasing productive powers.

As discussed above, the assertion that Smith built the foundations of The Wealth of Nations on a sociological understanding of land and labour is not only one that can be made regarding Book I, as in Small, but can just as well be made regarding Book II. When Smith divides capital into fixed capital and circulating capital, what forms the content of these two kinds of capital is the process of the metabolism of social product that depends on land and labour, or, in other words, the process of reproduction. Here, while on the one hand preaching the importance of productive labour, on the other hand Smith uses the agriculture, fishing and mining industries to enable him to understand the reason it forms the material foundation of social production. Goods and exchange value are nothing more than two sides of wealth. As a result the overall process of the production and reproduction of capital, and thus the process of capital accumulation, becomes the issue, and Smith having particularly emphasised a material foundation in this way, was not the result of his having become caught up in a technical perspective as Ammon says, nor was it an action emanating from a teleological, practical point of view; on the contrary, Smith penetrated the foundation of civil society, and this must be seen as having been because it was in line with his overall perspective. Small's 'sociology of capital' thus ends up arriving at a 'sociology of labour,' and it is for this reason that throughout Books I and II of The Wealth of Nations Smith was able to hold the view that the accumulation of capital is ultimately directly proportional to the degree of the productive powers of labour, and when the productive powers of labour are fixed it depends on the ratio of productive to unproductive workers. Of course, it is not as though Smith's having considered labour and land arrayed in this way cannot be seen as having been influenced by the physiocrats. As Smith's views in The Wealth of Nations progress one must indeed acknowledge that the traces of this influence are great. As was the case with distribution, however, here too we must be admonished against overestimating the influence of the physiocrats and seeing it as operating even in Smith's fundamental ideas. Just as human beings had been considered first as individual people, then as members of a family, then as subjects of a state, and finally in terms of international relations between nations (Lectures), here too human beings who apply their labour to nature are seen next as people who work in factories or commerce, and finally as people who work in 'a great commercial republic.' Smith has already stated that 'agriculture is of all other arts the most beneficent to society, and whatever tends to retard its improvement is extremely prejudicial to 
the public interest' (Lectures, p. 224). Indeed, issues concerning the special nature of natural resources and their allocation could not arise in Smith, but the promotion of the increase of the productive powers of labour dictates an order of the investment of capital in line with the order described above, and in this instance particular attention should be paid to the fact that for Smith international trade could be thought of as the result of an overflowing of domestic productive powers, and to this extent as natural course. This being the case, the unification of labour and land was something that corresponded to Smith's way of thinking from the start, and when this is viewed in terms of the process of reproduction as a whole, even if we can criticise Smith for not having been able to sufficiently develop the categories of capital on the basis of this way of thinking, we cannot criticise this approach itself. This is the case because it is precisely here, that is, within labour applied to nature, that we must seek the source of productive powers.

But while no particular difficulty arises in conjunction with Smith's having taken land as representative of nature in general, severe difficulties arise surrounding the social side of human beings being represented by labour. Just as the population in general is a meaningless abstraction when it comes to the issue of distribution, labour in general is nothing more than an abstraction when it comes to the issue of productive powers. In Smith, however, abstract labour was the source of productive powers-'Labour was the original purchase-money that was paid for all things' (The Wealth of Nations, p. 30) —and for this reason it was seen as the measure of value. Smith's labour value was almost without substantial content, and, as was later more thoroughly developed in Ricardo, was nothing other than a relative or relational value, but it is clear that a natural law conception of the person and the idea of justice lie hidden within the approach of measuring the exchange rate through an amount of labour and attempting to demonstrate the equality of value through its being equal. Since human beings are equal first as persons, labour as the manifestation of their power is equal, and it can therefore be understood that a one-for-one exchange is the fulfilment of justice. Smith thus discusses the distinction of nominal price and real price, but more than an introduction to the theory of distribution that comes later this passage can be described as one that ties the idea of the productive powers of labour to the process of circulation and attempts a unified understanding of money, price, and goods. This aim appeared in Ricardo as the inquiry into an invariable measure of value. Smith sought this first in gold and silver or in corn, and then ultimately in labour as the sole universal and accurate measure of value common to all times and places (p. 36), but the abstractness of labour Smith grasped still did not save him. For example, although Smith tried asserting 
that in general labour had the same value for all workers with normal health, physical capacity, and mental condition (p. 33), this abstractness of labour was only strengthened, and his attempt to say that differences in the quality of labour were evened out through dealings in the market, and that the rate of exchange of goods was almost precisely proportional to employed labour (p. 31), merely exposed the fact that here as in other cases labour and wages were being confused. It is natural that many people have viewed Smith's analysis on this point as ending in nothing but failure; it did not in fact make any contribution to his own subsequent theory of distribution, because the real price and natural price he described did not have any theoretical internal relationship to each other. After all, while natural price was the sum of wages, profits, and rent, real price was in a completely different category and had been conceived as a foundation for equivalence. Nevertheless, the trans-empirical character of natural price discussed above tacitly links arms with real price; natural price is spoken of not merely as a free competition price and midpoint between two poles, but also as an index of the maximised productive powers of labour and therefore the cheapest point in terms of price. This is where the biggest difficulty in Smith's economic theory-and eventually in Ricardo's-lies. In other words, ultimately it can be described in its entirety as an attempt to grasp an abstract concept of labour through the idea of natural law.

So far we have seen how the processes of production and reproduction have been sustained by the productive powers of labour that are the starting point of Smith's inquiry in The Wealth of Nations. We have also seen how this has been used as a foundation for equivalent exchange in the theory of real price, and thereby indirectly as part of an attempt to provide a basis for income determination. Even if Smith's 'system of natural liberty' was not 'plain and simple,' what remains solid after subtracting all of the contradictions, confusions, and errors from these attempts is the process of the development of productive powers as an overall process. This process includes all of circulation, distribution, production and reproduction, and can be described as the overall process of civil society which incorporates all of these factors within itself. However scholars may evaluate its other parts, our economic sociology attaches the greatest interest to this point, and the historical, subjective undertaking of transcending civil society while existing within it indeed revolves around the axis of this theory of productive powers. Here in terms of theory we find the problem of the subject of productive powers, and ultimately seem to be casting about for a bridge to take us from Smith to List. If so, how are we to attempt this move from Smith to List? We must now turn to this task of bridge-building. 


\section{Civil Society as a System of Productive Powers}

What we have tried to elucidate in the previous sections is civil society as a labour process. This is by no means a process that simply stands in opposition to circulation or distribution processes, but must instead be thought of as a unifying process that includes them as its inherent moments. As a result we must no longer think of the process of circulation, the process of distribution, and the process of labour as each having its own independent claim to being the fundamental principle in our understanding of civil society. Economic sociology rejects this kind of formal, non-sociological view. We emphasise that a truly comprehensive view of civil society is to be attained by sociologically theorising Smith's practical desires along these lines, avoiding all divergences, and to this extent we have presented the first two books of The Wealth of Nations as a topic for discussion with our own method. We thus ultimately arrived at a view of productive powers as the unification of nature and labour. In Smith, however, productive powers as the unification of nature and labour must be grasped not as the productive powers of nature but as the productive powers of labour. This is the case because to Smith civil society as an economic world had to be understood in particular through relationships of equivalent exchange, that is, through person-to-person relationships of social circulation, and therefore there was nothing in the natural world that could provide an appropriate measure for this equivalent exchange. To Smith the economic world was a world that could be properly thought of with exactness, and he did not think of this exactness simply in terms of the phenomenal aspect of money; Smith's intention seems to have been to try to grasp it with something more human. Even if social processes are inextricably linked to natural processes, the latter can only truly display their full significance within the former, and social processes are to all extents to be explained on the basis of what is human. This is well demonstrated in Smith's explanation of gold and silver as money. Smith's having seen that money, while being the physical materials of gold and silver, can become a measure of value and a means of circulation tells us, how at its roots an economy anticipates the unification of people and materials, and how moreover exchange value itself, while seemingly a proportional relationship between materials, can become a relationship that is no longer understandable on the basis of nature. Smith's productive powers can thus be understood as productive powers of labour. But if we were to accept Amonn's view, making the counter argument that, if we can see productive powers as the productive powers of labour, then by exactly the same rights we can surely also under- 
stand them as the productive powers of capital or the productive powers of land, this would have to be described as a formal critique that does not escape the old ways of the three elements of production theory. The unification of land and labour in Smith was thus understood as the productive powers of labour. In other words, Smith's concept of productive powers, while being based on material productive powers, must nevertheless be understood in human terms. It is here the reason that civil society as a comprehensive set of dependencies between individuals can be understood as a system of material productive powers mediated by labour is to be found. If we see Smith's labour measure as something that represented and made precise this kind of anthropocentric view, we may be close to understanding its true meaning.

People who take issue with Smith's concept of productive powers, and in particular his concept of wealth in relation to it, criticise it for being materialistic. This is the typical critique that, along with his being 'cosmopolitan (kosmopolitisch)' rather than political and individualist rather than nationalist, was levelled against Smith by German scholars beginning with Adam Müller and List. As we have already argued, however, the latter two criticisms, namely that Smith was individualist and cosmopolitan, are not necessarily on the mark. So what about the first criticism, that Smith's approach was materialistic? If this is aimed at Smith's view of society as a whole, then it is clear that it too, like the other two criticisms, is off the mark. This is the case because Smith studied the economic world under specific assumptions as one part of his overall system. If the criticism that Smith was materialistic is made regarding his concepts of productive powers and wealth, however, some closer examination is required. Regarding this point, List criticised Smith for seeing only exchange value and not what creates value, condemned his theory as nothing more than simply a theory of value, and tried to present his own theory of productive powers (Theorie der produktiven Kräfte) in opposition to Smith's approach. But our study of Smith has shown that he did not see only value and not productive powers, so to this extent, List's criticism, too, is clearly an arrow loosed without a proper target. But what List is trying to address here is not simply productive powers but the production of productive powers, and not simply the analysis of the structure of productive powers but its creation. For List, therefore, it is natural to emphasize theories of action over theories of analysis and subjective understanding over objective understanding. For Smith, in contrast, the objective was already undergoing maturation. To create it was to leave it to the natural course of things. Using all of Part 2 we have tried to show that Smith advanced the analysis of the objective in order to provide a foundation for this kind of policy, and to demonstrate how this was possible. For Smith, this kind of national founda- 
tion not present in List was a given. To say that Smith did not address productive powers is therefore close to a falsehood, but his emphasis was on understanding and measuring them objectively and not on creating them. Of course, to say that Smith did not address the creation of productive powers or something of the sort is also close to a falsehood, and the theory of the division of labour as a cause of the increase of productive powers shows how foundational the concept of the creation of productive powers was to him. It can be said, however, that Smith did not give a 'theory of productive powers' but rather gave a 'theory of value' for the purpose of understanding productive powers. It can presumably also be said that to Smith clarifying a 'theory of value' at the same time meant providing a theory of productive powers. When it came to his attempt to objectively understand productive powers, however, while adopting the perspective of human productive powers Smith often shifted into the perspective of material productive powers. Using corn to measure value, explaining productive labour as labour that produces materials that can be seen and touched, and arguing that wastefulness that destroys materials is the form of wastefulness most damaging to the accumulation of capital-such examples show that in explaining human economic relationships Smith often lapsed into the viewpoint of materials, and indicate that this is where his confusion lay. As a result, in this sense, it is possible to say that he was materialistic. List also criticises Smith for seeing only material production while ignoring intellectual production and for looking only at the division of labour and not its unification, but neither of these claims is correct. Smith's thoughts on joint labour along with the division of labour, the fact that probity and punctuality are both a cause and result of commercial development, and the question of the extent to which political organisations, social systems, and various judicial, governmental, and educational institutions affect the development of a country's productive powers are all considered from multiple angles in the Lectures and The Wealth of Nations. On this basis we cannot conclude that Smith was materialistic. The perspective of human productive powers in Smith does not allow for this kind of materialism from the start. More or less the same can be said regarding the concept of wealth in Smith, but we will not enter into a discussion of this here. Notwithstanding these interpretations that are all sympathetic to Smith, then, what is it that separates Smith and List and assigns them intractably opposed destinies? It is the fact that while there is rich content concerning productive powers in Smith, there is no theory of productive powers. Today's leading scholars of List pay special attention to the theory of productive powers rather than the idea of productive powers in List, and argue for his superiority in this regard not only in comparison with Smith but also with Adam Müller. List's theory 
of productive powers stands on a completely different practical intention and intellectual structure that ultimately cannot be understood from within the socio-political environment and the intellectual domain of natural law in which Smith was cultivated, and is referred to as a "theory of national productive powers' (Theorie der nationalen produktiven Kräfte). We have thus reached the outer limit of our study of Smith. Now we must move on and consider List's 'theory of national productive powers.'

The above has presented an economic sociology consideration of the issue of civil society in Adam Smith. We have analysed Adam Smith's views concerning what we presented as the fundamental problem in economic sociology at the end of Part 1, namely, the issue of the state and civil society, along with his view of civil society as a system of productive powers. By doing so, on the one hand we showed the extent to which the view of civil society developed in Britain was not only historical but also sociological, and indeed not only sociological but a supremely economic conception. On the other hand, through this analysis we also elucidated the connection between the moral world and both the legal and economic worlds in Smith, and showed how the state can be absorbed by civil society without completely dissolving into it. Finally, we then tried to prove that civil society as a supremely economic world formed in this way was understood and must be understood as a system of productive powers. Seen as a synthesis, Smith's view of civil society was at its root idealistic and not materialistic, but nevertheless his socio-philosophical method, namely, the principle of 'sympathy,' enabled him to have great success in impartial observation through inquiring into our familiar world of the economy. Having reached this point, along with Oncken we can see 'a stance in which German idealism attempts to merge and become one with Anglo-French realism' (A. Oncken, Adam Smith in der Kulturgeschichte, 1874, p. 20). It must therefore be said that Smith occupied this sort of important position not only in the history of economics but also in the history of culture.

Nevertheless, Smith was indeed a child of his time. As we have already seen, his theory that tied together the moral world, the legal world, and the economic world was underpinned by a sense of harmony. In the economic world this was supported by natural price as a central point. For us today, however, this sense of harmony is not one with which we can necessarily sympathise. And even if in Smith the state or nation does not dissolve within civil society but on the contrary continues to live within in it, and Smith's 
economics was indeed the starting point of 'political economy,' today, in the midst of an era of the dismantling of civil society itself, this view of the state is presumably not one that can be accepted as is. To put it another way, first, while it is not as though there is no whole in Smith, there is only the whole as it was seen, not a whole in the true sense as it ought to be created. No matter how powerful the practical efficiency demonstrated by laisser-faire thought may be, from today's perspective, Smith's policy can surely be described as policy without policy, and his whole as a whole without a whole. People today do not search for the whole empirically in this sense, but try to directly pick it up and see it for themselves. That is, in comparison to Smith's whole it must include a more metaphysical colouring. List's concept of the national productive powers was precisely this kind of concept of wholeness. Second, the reason Smith does not satisfy us today is that he lacks a logic of creation. This is connected to the fact that his approach is underpinned by a sense of harmony and his analysis employs the idea of natural law. Of course, as we have repeatedly argued, we know that this approach and form of thought on the contrary served him well as a vessel for his rich sense of history. But when it comes to an understanding of the fact that civil society develops and creates itself as a whole, this is something we cannot expect from Smith. Among the members of the orthodox school, for this we must instead look to Ricardo, because he was in fact the first proponent of thought focused on development to emerge within this school (Briefs, Untersuchungen zur klassischen Nationalökonomie, 1915). That being said, it is of course not as though there is no thought concerning the progress or regress of society in Smith's passages dealing with the theory of wages and the natural development of the progress of wealth, nor, as we have mentioned, is it as though a theory of the stages of economic development that seems to prefigure List did not exist in Smith. Nevertheless, the civil society seen by Smith can be viewed as a society contemplated under the aspect of eternity. Here it is important for us to note that, later, during the period when developmental thought in Britain was first displaying British advances in the form of Darwinism and the sociology of Spencer, in Germany the consciousness of history was awakened through the spiritual flourishing of the Romantics, and through this being tied to List's practical desires history became a history that flowed toward us rather than one that simply flowed away from us, and turned from a history that has already been created into one that is about to be made. This is where the reason for List's resurgence in an era of the dismantling of civil society is to be found. Of course, as we will make clear later, it is not as though dregs of the idea of natural law did not remain in List's thought. This is something that must be overcome in modern interpreta- 
tions of List, but it is rather curious that these dregs of natural law in List tie him to Smith. We are attempting to interpret Smith through List and List through Smith. Now half of this aim seems to have been achieved, and next we must turn to the other half. Here our inquiry will presumably be guided by the concepts of wholeness and historical development.

(Robert Chapeskie: Freelance Translator) (Akio Hoshino: Professor Emeritus, Kanto Gakuin University) 